University for Business and Technology in Kosovo

UBT Knowledge Center

Nov 8th, 9:15 AM - 9:30 AM

\title{
The impact of affirmative action policy on the employment of women in the private sector: the case of Saudi Arabia
}

\author{
Abdullah Alothman \\ Plymouth University, abdullah.alothman@plymouth.ac.uk \\ Atul Mishra \\ Plymouth University, atul.mishra@plymouth.ac.uk
}

Follow this and additional works at: https://knowledgecenter.ubt-uni.net/conference

Part of the Business Commons

\section{Recommended Citation}

Alothman, Abdullah and Mishra, Atul, "The impact of affirmative action policy on the employment of women in the private sector: the case of Saudi Arabia" (2014). UBT International Conference. 48. https://knowledgecenter.ubt-uni.net/conference/2014/all-events/48

This Event is brought to you for free and open access by the Publication and Journals at UBT Knowledge Center. It has been accepted for inclusion in UBT International Conference by an authorized administrator of UBT Knowledge Center. For more information, please contact knowledge.center@ubt-uni.net. 


\title{
The impact of affirmative action policy on the employment of women in the private sector: the case of Saudi Arabia
}

\author{
Abdullah Alothman ${ }^{1}$, Atul Mishra ${ }^{2}$ \\ ${ }^{1,2}$ Plymouth University \\ Business \& Management, School of Business, United Kingdom \\ 1abdullah.alothman@plymouth.ac.uk ${ }^{2}$ atul.mishra@plymouth.ac.uk
}

\begin{abstract}
The principal goal of Affirmative Action policy around the world is to equalise opportunities and to increase the share of employment for minority groups and females. The Saudi Arabian Affirmative Action is no exception; since 1985, it has been a crucial means of ensuring 'fair participation' in employment for Saudi citizens. This policy, known as 'Saudisation', aims to tackle labour market issues by replacing the high volume of foreign workers with Saudi nationals. However, one of the major criticisms of the policy has been its failure to increase the number of females in private sector employment. Women still comprise a very low proportion of this sector, compared to men. Nevertheless, some argue that the active role of 'Saudisation' has brought some positive changes, as some trends show that women's share of employment in certain sectors, i.e. banking, has been rising significantly. Nevertheless, the lack of comprehensive data required to analyse the impact of such a policy on women's employment has made it difficult to determine the extent of its effect. The role of Affirmative Action (Saudisation) in female employment in the private sector in past decades is at the core of the investigation in this study. Unlike former studies on this subject, this research attempts to investigate the long term effect of the policy by applying an event study uniquely suited to a historical exploration of this issue. This method examines variations during the period 1990 to 2014, in order to identify and evaluate the effectiveness of the policy in promoting fair employment for women across the private sector. This will be the first study to document broadly and comprehensively the long-term effect of Saudisation policy on the employment of females in the private sector.
\end{abstract}

Keywords: Affirmative Action, Women's Employment, Private Sector, Saudi Arabia, Saudisation

\section{Introduction}

Saudi Arabia is one of the fastest developing countries in the world. Since the discovery of oil in the 1930s, it has transformed itself from one of the world's poorest countries, reliant on limited agriculture and pilgrimage revenues, to one of the wealthiest and advanced states in the world. Saudi Arabia's development was relatively modest in the period between the 1930s and the 1960s (Al-Jasser, 2002). Subsequently, as oil revenues boomed, and into the early $1980 \mathrm{~s}$, the country instigated fast track development; transforming its few miles of paved roads into a modern network covering thousands of miles, linking almost all the Kingdom's cities and towns. Massive development and growth also took place in the areas of education, healthcare and other essential services.

However, at that time, the Saudi Arabian population was not sufficiently well trained and qualified to manage the enormous development projects instigated in response to their nation's sudden wealth. Thus, the government sought help with its plans for swift development. This involved importing and recruiting a huge number of foreign workers, and allowing the private sector to engage in unrestricted recruitment of expatriates, in order to develop a modern infrastructure. Moreover, throughout that period, as improvements in the educational infrastructure took hold, the government recognised the importance of securing the public sector through the employment of local labour. It chose to promote its citizens to governmental jobs, which attracted higher salaries and greater job security (Al-Humaid, 2002). Crucially the strategy of promoting citizens to public sector jobs has produced long-lasting employment 
practices in the labour market (see figure 1), shaping the characteristics of both private and public sector employment. In other words, the strategy has led many Saudi nationals to prefer to work in the government sectors, and to abandon the private sector. Meanwhile, the government permitted the private sector to practice unrestricted recruitment of cheap foreign labour. As a result, the private sector became almost entirely reliant on expatriates (Fakeeh, 2009).

In order to address this potentially serious threat to the economy, the Saudi government responded by introducing its own affirmative action (AA) policy in 1985, known as 'Saudisation', which aimed to tackle the growing problem of the proportion of foreign workers in the labour market, and to improve citizens' opportunities to work in the private sector. This policy has evolved and changed over time; however, its critics still believe that it has not achieved any of its stated goals (Al-Khouli 2007; Alanezi 2012). Indeed, in the case of women's employment, the situation appears to have worsened, as current estimates state that the female unemployment rate is as high as $35.7 \%$ (The Economist, 2014). Women comprise a very small proportion of the Saudi labour force; $15 \%$ of the total, with fewer than $2 \%$ employed in the private sector (SAMA, 2011). This is significantly lower than the international average, and compares poorly with the number of females in public sector employment.

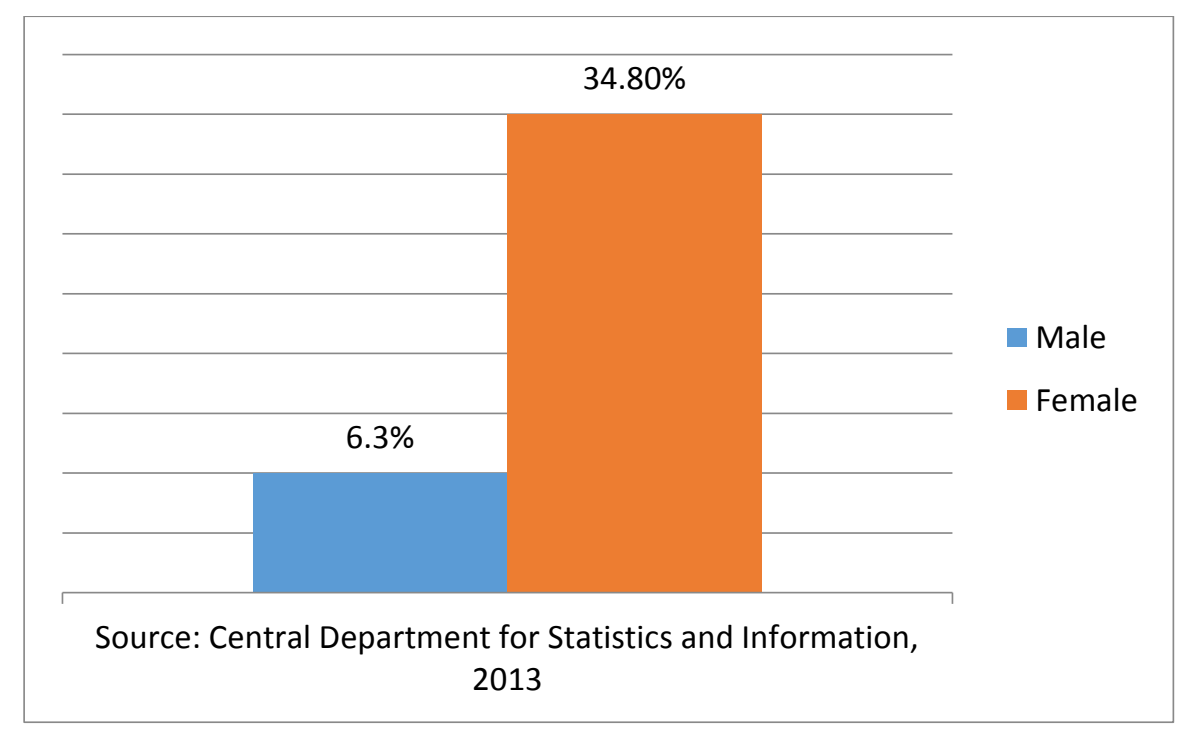

Fig. 1. Unemployment rates by gender

Source: Central Department for Statistics and Information, 2013

\section{Literature review}

\subsection{The Concept of Affirmative Action}

Governments worldwide aim to protect, improve and equalise the living conditions of their citizens. Governments faced with serious issues like discrimination, have found that the law has limitations when used as a means of resolving social disputes (Rulof, Burger \& Jafta, 2010). Therefore, AA has been introduced to address such issues. The concept of AA is generally considered to have originated in the USA. It dates to 1961, when the term 'affirmative action' was introduced under an executive order by President John F. Kennedy, as a method of redressing and eliminating profound and rooted 
discriminatory social practices believed to be affecting the progress of equality in a society (Cahn, 2013). This subsequently led to its adoption by many other countries, for similar reasons.

AA can be generally identified as "A generic term for programmes which take some kind of initiative, either voluntary or under the compulsion of law, to increase, maintain, or rearrange the number or status of certain group members usually defined by race or gender, within a larger group" (Bacchi, 1996; x). Furthermore, it "refers to a broad set of social policies aimed at reversing historical trends that have located minority groups in a disadvantaged position mainly in work, education and political institutions" (Martiniello, 2001; 4). In other words, AA can be seen as a set of measures implemented by governments, in both public and private organisations (i.e. educational establishments and political parties and companies), to address historic discrimination against, and exclusion of, certain social groups. Therefore, AA policy sets out to improve the indicators of development by reducing socioeconomic inequalities and facilitating the involvement of certain social groups in economic development.

However, it is important to emphasise that the term AA is not always used in the same way in different countries. For instance, the concept is better known as 'Employment Equality' in Canada, 'Positive Action' in the UK, 'Reservation' in India and 'Localisation' in the Gulf Corporation Council states (GCC). Indeed, even within the GCC, AA is known by different names, for example 'Emiratisation' in the UAE and 'Saudisation' in Saudi Arabia (Klarsfeld, 2010).

Table 1. Names and Concepts of AA around the world.

\begin{tabular}{|c|c|c|c|}
\hline Country & Name & Concept & ref \\
\hline Saudi Arabia & Saudisation & $\begin{array}{l}\text { Is a comprehensive policy to } \\
\text { tackle inequality amongst } \\
\text { majority citizens by reducing the } \\
\text { substantial reliance on foreign } \\
\text { labour and by preparing and } \\
\text { equipping citizens with the } \\
\text { necessary skills to take over jobs. }\end{array}$ & $\begin{array}{l}\text { (Baldwin-edwards, } \\
\text { 2011)(Al-Khouli, } \\
\text { 2007)(Al-Dosary } \\
\text { Rahman, 2009) }\end{array}$ \\
\hline India & Reservation & $\begin{array}{l}\text { Is an elaborate quota system for } \\
\text { public jobs, places in publically } \\
\text { funded colleges and in most } \\
\text { elected assemblies. These must } \\
\text { be filled by members of } \\
\text { designated and disadvantaged } \\
\text { groups. }\end{array}$ & (Sahoo, 2010) \\
\hline USA & $\mathbf{A A}$ & $\begin{array}{l}\text { Was the first policy of this kind. } \\
\text { It aims to tackle discrimination } \\
\text { and raise the profile of } \\
\text { disadvantaged groups and } \\
\text { women in education and } \\
\text { workplace. }\end{array}$ & (Krstic, 2003) \\
\hline Canada & $\begin{array}{l}\text { Employment } \\
\text { Equality }\end{array}$ & $\begin{array}{l}\text { Is a policy designed to increase } \\
\text { the employment representation } \\
\text { of four designated groups: } \\
\text { women, disabled people, } \\
\text { Aboriginal peoples, and visible } \\
\text { minorities. }\end{array}$ & $\begin{array}{l}\text { (Jain, Sloane, \& Horwitz, } \\
\text { 2003) }\end{array}$ \\
\hline
\end{tabular}




\begin{tabular}{|c|c|c|c|}
\hline Malaysia & $\begin{array}{l}\text { Bhumiputra or } \\
\text { New Economic } \\
\text { Policy }\end{array}$ & $\begin{array}{l}\text { Is a policy designed to help } \\
\text { Bhumiputra (sons of the soil) } \\
\text { people to gain jobs and } \\
\text { educational opportunities after } \\
\text { their isolation following } \\
\text { Independence. }\end{array}$ & (Mandla, 2006) \\
\hline South Africa & $\begin{array}{l}\text { Positive } \\
\text { discrimination }\end{array}$ & $\begin{array}{l}\text { Is a policy intended to redress the } \\
\text { inequality issues affecting the } \\
\text { majority black population. It is } \\
\text { intended to help raise their } \\
\text { representation in the education } \\
\text { and labour markets. }\end{array}$ & $\begin{array}{l}\text { R Burger \& Jafta, (2010) } \\
\text { Sowell, (2004) }\end{array}$ \\
\hline United Kingdom & positive action & $\begin{array}{l}\text { Is a policy designed to tackle } \\
\text { discrimination against } \\
\text { minorities, which takes factors } \\
\text { such as gender, race, sexual } \\
\text { orientation and age into } \\
\text { consideration, in order to benefit } \\
\text { under-represented groups. }\end{array}$ & (Sowell, 2004) \\
\hline
\end{tabular}

\subsection{Affirmative Action A In Relation To Employment}

The existing literature provides a wide range of discussion by academics regarding AA policies, their effectiveness and their relation to employment. The principal objective of AA policies is to equalise opportunities and raise minority representation across workplaces and educational institutions (Kurtulus, 2011), as well as fight racism and other racial disparities. It is necessary to overcome the systemic barriers that prevent minorities and disadvantaged groups from becoming actively involved in society, and to enable these groups to access education and employment opportunities (Orfield, 2001).

In the developed world, many studies, viz. Kurtulus (2011), Krstic (2003), Abdullah (1997) and Cahn (2013), have indicated that there is a positive connection between AA and employment. These policies have proved economically advantageous, as they have created new job opportunities for disadvantaged groups. For instance, in the USA, "long term trends indicate that minority and female shares of employment in large U.S. firms have been rising since the 1960s" (Kurtulus 2011: 1). Moreover, another study has been conducted to examine the impact of eliminating AA in some US States, (California eliminated AA in public employment in 1996; Washington in 1998; and some other states followed suit). The findings revealed a sharp decline in the representation of disadvantaged groups in public employment immediately following the elimination of AA (Kurtulus, 2013). Furthermore, Muttarak et al. (2012) encountered similar instances in their study of Northern Ireland, in which they examined and evaluated the efficiency of AA policies in promoting fair employment for both Protestants and Catholics in the province. Their results show that AA not only had a positive effect on the share of employment of under-represented groups, but also, by defusing political tensions, contributed to the Northern Ireland peace process.

Nevertheless, Burger and Jafta (2010) presented a contradictory result. Their study attempted to examine the effect of AA on labour market outcomes and employment. It revealed no strong evidence to support the connection between AA and enhancement of employment. In fact, there is evidence to suggest that it has failed to reduce the employment or wage gap, and that discrimination still exists. Moreover, the labour market outcomes were not improved by the policy. Another study, compiled by the Solidarity Research Institute (2008), shows similar instances regarding the outcome of AA in South Africa. It has revealed that AA failed there because the country's policies did not keep pace with the profound changes in the international climate regarding AA. 
Furthermore, elsewhere, the impact of AA policies on employment in developing countries has been both controversial and debatable. For instance, the Malaysian version of AA, known as the New Economic Policy (NEP), has been broadly discussed. Some studies, such as Snodgrass (1995), Tladi (2001), Emsley (1996), Barnett, Namasivayam, \& Narudin (2010) and Lee (2012), have revealed evidence that NEP had a significant impact on the economy as whole and employment in particular. The targeted group, the Bumiputra (Locals or Sons of Soil) has seen its economic gains rise significantly. Meanwhile, poverty rates have fallen sharply, from nearly 50\% in 1970 to only $3.8 \%$ by 2009 (Thorat, 1997). In addition, the income and employment inequality between 'Bumiputra' and other ethnicities declined markedly during the period of the policy enforcement.

Howard and Prakash (2011) investigated the impact of Indian AA (Reservation) on disadvantaged minority groups in India. They discovered a positive relationship between the enforcement of the policy and the level of employment of underrepresented groups. They claim that AA has had some positive impact on the occupational selections and advancement of individuals within the target groups. However, other studies such as Jaffrelot (2006) and Thorat (2005), found no real benefits from the Reservation, and that the socioeconomic situation in India remains largely unchanged.

AA within the Gulf Cooperation Council (GCC) states has been broadly discussed and is controversial. Based on a number of studies, notably Al-Mahmoud (2012), Zerovec and Bontenbal (2011), Sadi (2013), Torofdar (2011) and Ramady (2013), AA polices have brought advantages to local economies and boosted job creation. Furthermore, AA is considered a crucial factor in confronting economic issues, i.e. unemployment. AA polices across all GCC states have achieved positive results in the private sector, especially within the banking sector. For instance, in Saudi Arabia, more than $90 \%$ of bank employees are Saudi nationals (Kiznidar, 2014).

In contrast, Da-Ghstani (2000) and Al-Hammad (2001) argue that AA has brought no real benefits to local economies, but rather has created complex issues in labour markets, such as skills shortages and declining efficiency. In addition, they believe that AA has not influenced levels of employment significantly, as unemployment remains too high within the GCC. Furthermore, Alabdelkarim et al. (2014) found that in the Emirates, AA (Emiratisation) has made only a marginal contribution to overall job creation. In some sectors, it has actually led to job dissatisfaction and disruption of the work environment. Jang (2005) finds similar instances in Saudi Arabia. He believes that AA in Saudi Arabia (Saudisation) has not resulted in any significant increase in employment, particularly within certain sectors, e.g. manufacturing.

As mentioned previously, this diversity of opinions regarding the effectiveness of AA is predictable. There are a number of reasons for this, in particular the fact that the application and effect of AA differs from country to country (Sowell, 2004). For example, in Malaysia the policy appears to have had a more positive effect than in South Africa, where it attracted strong criticism. Another reason is that AA is not equally effective across all sectors. This means that the opponents of AA have considerable scope for criticising it from different perspectives. This could explain the apparent contradictions between studies conducted within the same country; as in Saudi Arabia, where AA studies undertaken within the banking sector seemed to be more positive toward AA (Saudisation), whilst others carried out within the manufacturing sector described it as a less promising policy. Criticism of AA within Saudi Arabian context seems to have declined gradually in recent years (Hertog, 2012), possibly due to the situation in Saudi Arabia, where the contribution of AA has become steadily more visible, especially in certain sectors such as banking, as stated earlier (Shediac, 2010).

There is an ongoing debate about the effectiveness of AA on employment in general and on the employment of disadvantaged groups in particular. However, there are reasons for asserting that AA positively affects the national employment level of women and other traditionally disadvantaged groups. 


\section{Context and Importance of the Study}

This study is concerned with discussing the impact of AA ('Saudisation') on female employment in the Saudi Arabian private sector. As discussed, although AA policies have resulted in an enhancement of their situation, full equality for women in terms of employment does not yet exist, and the female unemployment rate in Saudi Arabia remains one of the highest in the region. The level of participation in the labour market by women remains very low, especially in the private sector. This study will therefore adopt a unique approach to investigating the issue, by reviewing the history of the Saudisation policy in an attempt to find the best solution to the continuing problem of female inequality in the workplace.

\section{Research Aim}

The overall aim of this research is to understand and explain, through historical analysis, the relation between Saudisation and patterns of both general and female employment in the private sector. It will also investigate how government intervention in the private sector affects employment in general, and female employment in particular.

\section{Data and Methodology}

This paper is based on an empirical study that employs both quantitative and qualitative methods of analysis (mixed methods) to examine the impact of Saudi Arabia's AA policy (Saudisation) on the employment of women. Due to the sensitivity of the topic and the scarcity of major research in this area, an effective method is required. This study will therefore implement a unique research method, the event study. This is a powerful tool, which can help researchers to assess the impact of certain types of change on corporate bodies effectively (McWilliams and Siegel 1997). Event study has hitherto been used principally in relation to accountancy and finance studies; however, more recently its application has been expanded to cover other disciplines, including management, economics, and even law and political studies (McWilliams and Siegel 1997).

In the study described herein, this technique will be used to examine all available employment data (1990 to 2014) from various Saudi government sources. It will include details of all employment policy decisions made during the stated period, along with figures showing variations in levels of employment. This will enable the researcher to identify the impact of each individual decision relating to AA (Saudisation), on employment levels, making it possible to identify the extent to which AA (Saudisation) impacts on the employment of women. In addition, this method will be supported by semistructured interviews with labour market experts and government officials involved in female employment affairs, in order to reinforce understanding of the issues involved.

\section{Results and Implications}

The GCC region continues to face substantial issues related to increasing rates of unemployment among nationals, especially in Saudi Arabia, and in particular among women. In addition, the growing reliance on foreign labour is still threatening local economies. Former studies on this subject, particularly in relation to this context, have been mostly descriptive in nature and limited in scope. Therefore, this study intends to investigate this complicated issue more broadly, and from a different perspective, using unique methods to allow deeper understanding of the on-going situation. The anticipated results will assist policy makers in understanding and identifying the best strategy to encourage increased female participation in the workforce. It is anticipated that this research will ultimately help to shape future 
policies, resulting not only in increased employment opportunities for women, but creating a more stable economy through the creation of more jobs for GCC nationals.

\section{References}

1. Abdullah, F. H. (1997). AA Policy in Malaysia: To Restructure Society, to Eradicate Poverty, XV(2).

2. Alabdelkarim, A., Muftah, M., \& Hodgson, S. (2014). The Impact of Emiratisation on Job Description Issues. Middle East Journal of [Online] Retrieved from http://www.mejb.com/upgrade_flash/April2014/Job Desc.pdf

3. Alanezi, A. (2012). Workforce Localization Policies In Saudi Arabia: The Determinants Of Successful Implementation In Multi-National Enterprises, 957-968.

4. Al-Dosary, A., \& Rahman, S. (2009). The role of the private sector towards Saudisation (localisation). International Journal of Arab Culture, Retrieved from http://inderscience.metapress.com/index/t274v12071p1xtp1.pdf

5. Al-Hammad, I. (2001). Case Study of Saudization in Construction Project Development. Engineering Sciences. Retrieved from http://www.kau.edu.sa/ShowRes_EN.aspx?Site_ID=320\&RN=52662

6. Al-Khouli, A. (2007). Labour Shortages, Migration, and Segmentation: The Case of Saudi Labour Market, 1-9.

7. Al-Mahmoud, S. (2012). Saudisation of the nursing workforce: Reality and Myths about planning Nurse Training in Saudi Arabia. Journal of American ... Retrieved from http://www.jofamericanscience.org/journals/am-sci/am0804/050_8757am0804_369_379.pdf

8. Bacchi, C. (1996). The politics of AA:'women', equality and category politics. Retrieved from http://books.google.co.uk/books?hl=en\&lr=\&id=XMNRLmmofmsC\&oi=fnd\&pg=PR9\&dq=Affirmativ $\mathrm{e}+$ Action+definition\&ots=Ha47YS5YMh\&sig=97ZMC-GXL4_KUD5JQNLs7SvQpUw

9. Baldwin-edwards, M. (2011). Labour immigration and labour markets in the GCC countries: national patterns and trends, (15).

10. Barnett, T., Namasivayam, P., \& Narudin, D. a a. (2010). A critical review of the nursing shortage in Malaysia. International Nursing Review, 57(1), 32-9. doi:10.1111/j.1466-7657.2009.00784.x

11. Burger, R., \& Jafta, R. (2010). AA in South Africa : an empirical assessment of the impact on labour market outcomes, (76).

12. Burger, R., \& Jafta, R. (2010). AA in South Africa: an empirical assessment of the impact on labour market outcomes. CRISE (Centre for Research on Inequality, .... Retrieved from

http://r4d.dfid.gov.uk/pdf/outputs/inequality/workingpaper76.pdf

13. Cahn, S. (2013). The AA debate. Retrieved from $\mathrm{http}: / /$ books.google.co.uk/books?hl=en\&lr=\&id=fLJlAgAAQBAJ\&oi=fnd\&pg=PP1\&dq=role + of + affir mative+action\&ots=SypDxJ_0KJ\&sig=T9wmg1XuxzXKRCQOwiKjZPBK4MI

14. Da-Ghstani, A. (2000). Saudisation of Labour Market in Saudi Arabia. Riyadh, Saudi. Retrieved from http://scholar.google.co.uk/scholar?q=saudisation $+\& b t n G=\& h l=e n \& a s \_s d t=0,5 \# 7$

15. Emsley, I. (1996). The Malaysian experience of AA: lessons for South Africa. Retrieved from http://www.getcited.org/pub/100201988

16. Hertog, S. (2012). Steffen Hertog A comparative assessment of labor market nationalization policies in the GCC Book section.

17. Howard, Larry and Prakash, N. (2011). Do employment quotas explain the occupational choices of disadvantaged minorities in India?

18. Jaffrelot, C. (2006). The impact of AA in India: more political than socioeconomic. India Review. Retrieved from http://www.tandfonline.com/doi/full/10.1080/14736480600824516

19. Jain, H., Sloane, P., \& Horwitz, F. (2003). Employment equity and AA: An international comparison. Retrieved

from http://books.google.co.uk/books?hl=en\&lr=\&id=GSkEd0omx_UC\&oi=fnd\&pg=PR9\&dq=The+Role + o $\mathrm{f}+$ Affirmative + action + on + minorities + and + women\&ots $=$ miNHu_BH\&sig=13sBdXxfETyoAa90Y9B8zf6bPLw

20. Jang, G. (2005). An Evaluation of Economic Globalization in Saudi Arabia. Retrieved from http://scholar.google.co.uk/scholar? $\mathrm{q}=$ Saudization+evaluation\&btnG $=\& \mathrm{hl}=\mathrm{en} \& \mathrm{as} \_\mathrm{sdt}=0,5 \# 4$

21. Kiznidar, A. (2014). No Title. Alwatan Newspaper. Retrieved from http://www.alriyadh.com/913138

22. Klarsfeld, A., Employment, W., \& Business, T. (2010). Perspectives from 16 on Diversity and Equal Treatment at Work An overview and transverse questions.

23. Krstic, I. (2003). AA in the United States and the European Union : Comparison And Analysis, 1, 825843. 
24. Kurtulus, F. A. (2011). The Impact of AA on the Employment Of Minorities and Women over Three Decades: 1973-2003, 1-3.

25. Kurtulus, F. A. (2013). The Impact of Eliminating AA on Minority and Female Employment : A Natural Experiment Approach Using State-Level AA Laws and EEO-4 Data, (413), 1-21.

26. Lee, H. (2012). AA in Malaysia: Education and Employment Outcomes since the 1990s. Journal of Contemporary Asia. Retrieved from http://www.tandfonline.com/doi/abs/10.1080/09500782.2012.668350

27. Mandla, B. (2006). BEE and Malaysia's NEP: a comparative study. Retrieved from http://ir1.sun.ac.za/handle/10019.1/2412

28. Martiniello, M. (2001). AA and Racism.

29. McWilliams, A. and Siegel, D. (1997). Event studies in management research: Theoretical and empirical issues. Academy of Management Journal, Vol. 40, No. 3.

30. Muttarak, R., Hamill, H., Heath, A. \& McCrudden, C. (2012). Does AA Work? Evidence from the Operation of Fair Employment Legislation in Northern Ireland. Sociology, 47(3), 560-579. doi:10.1177/0038038512453799

31. Orfield, G. (2001). Diversity Challenged: Evidence on the Impact of AA. Retrieved from http://files.eric.ed.gov/fulltext/ED456190.pdf

32. Ramady, M. (2013). Gulf unemployment and government policies: prospects for the Saudi labour quota or Nitaqat system. International Journal of Economics and Business Research, 5(4), 476. doi:10.1504/IJEBR.2013.054266

33. Sadi, M. (2013). The Implementation Process of Nationalization of Workforce in Saudi Arabian Private Sector: A Review of "Nitaqat Scheme." American Journal of Business and Management. Retrieved from http://www.worldscholars.org/index.php/ajbm/article/view/273

34. Sahoo, N. (2010). Private Sector Participation in Affimative Action in Malaysia: Lessons for India.

35. SAMA. (2011). Forty Seventh Annual Report.

36. Shediac, R. (2010). Meeting the Employment Challenge in the GCC The Need for a Holistic Strategy.

37. Snodgrass, D. (1995). Successful Economic Development in a Multi-Ethnic Society: The Malaysian Case.

38. Sowell, T. (2004). AA around the world: an empirical study. Retrieved from $\mathrm{http} / /$ books.google.co.uk/books?hl=en\&lr=\&id=jsir5JhDeREC\&oi=fnd\&pg=PR7\&dq=affirmative + act ion+around+the+world\&ots=trV0E101-R\&sig=ZljkWmnvC5Du3SxCFnoZBD4cZs0

39. Thorat, S. (1997). New Economic Policy and its Impact on Employment and Poverty of the Scheduled Castes. New Economic Policy \& Dalits. Retrieved from http://scholar.google.co.uk/scholar?q=NEP+impact + on+employment\&btnG $=\& h \mathrm{hl}=$ en\&as_sdt=0,5\#4

40. Thorat, S. (2005). Reservation and efficiency: Myth and reality. Economic and Political Weekly. Retrieved from http://www.jstor.org/stable/4416261

41. Tladi, T. M. (2001). Chapter One AA Chapter Two A Normative Definition Of AA. (July).

42. Torofdar, Y. (2011). Human Resource Management (HRM) in Saudi Arabia: A Closer Look at Saudization. Riyadh, Saudi Arabia: Institute of Public Administration. Retrieved from http://www.wbiconpro.com/715-Torofdar.pdf

43. Zerovec, M., \& Bontenbal, M. (2011). Labor Nationalization Policies in Oman: Implications for Omani and Migrant Women Workers. Asian Pacific Migration Journal. Retrieved from http://www.smc.org.ph/administrator/uploads/apmj_pdf/APMJ2011N3-4ART5.pdf 